\title{
The competitiveness of ferry and air transport in the Baltic Sea Region: infrastructure approach
}

\author{
Marta Mańkowska², Dariusz Tłoczyński ${ }^{2}$ \\ ${ }^{1}$ Faculty of Management and Economics of Services, University of Szczecin, 8 Cukrowa St., 71-004 \\ Szczecin, Poland, e-mail: marta.mankowska@wzieu.pl \\ ${ }^{2}$ Presenting author: Faculty of Economics, University of Gdańsk, 119/121 Armii Krajowej St., 81- \\ 824 Sopot, Poland, e-mail: dariusz.tloczynski@ug.edu.pl
}

\begin{abstract}
The main aim of the article is attempt to get the answer to the question about the impact of services offered by point elements of transport infrastructure on meeting the expectations and preferences of passengers in various modes of transport. Based on the presented objective, the assessment of the competitiveness of air and ferry transport in the service of passenger traffic was carried out through taking into the consideration selected elements affecting the quality of services offered by airports and ferry terminals. One of the key factors of the competitiveness of ports is time availability. The main objective of the research undertaken in the article was therefore to assess the competitiveness of seaports and airports in terms of their time availability. The article uses the case study method of selected airports and ferry terminals located in the Baltic Sea Region (BSR). The comparative analysis covered the time competitiveness of port ground access. The results of the research allow to make a general conclusion that ferry terminals have better ground access for individual car journeys and airports are becoming more competitive in the case of the arrival and departure function of public transport. This indicates that the system of ground access for seaports and airports is adapted to the segment of passengers having the largest share in transport by the analyzed transport branches, i.e. the motorized passengers in ferry transport and non-motorized passengers in air transport.
\end{abstract}

\section{Introduction}

The phenomenon of competition between sea transport (ferry shipping) and air transport intensified in the 1990s. The weakening of the competitive position of ferry transport contributed primarily to the introduction in 1999 of the abolition of duty-free and tax-free retailing on board ferries operating on ferry lines connecting the EU member countries [1-3]. On the other hand, the increase in the competitiveness of air transport was related to the development of low-cost airlines supported by the liberalization of the EU air transport sector and the implementation of the open sky policy in the EU [4-8]. As a result of the changes, the function of ferry shipping changed from a typical passenger to a passenger and cargo shipment. The outcome was the conversion of passenger ferries and the introduction of new ro-pax ferries with an extended lane metres at the expense of the passenger space. 
These factors changed the structure of the international passenger transport market in the Baltic Sea Region (BSR), which was traditionally dominated by ferry transport. The increase in cost competitiveness and the time advantage of air transport, while the competitiveness of ferry shipping decreased due to abolition of duty-free sale, contributed to the takeover of some of the passengers of the ferries by air transport. The few surveys undertaken so far in the area of competitiveness of air and sea transport focused on the analysis of the demand side, including in particular identification of passengers' preferences as regards the choice of modes of transport. There is, however, no comparative research in the area of inter-branch competitiveness of air and sea transport from the point of view of the quality of services provided by seaports and airports. One of the key elements influencing the quality of airport services is their time of port ground access.

The main aim of the article is attempt to get the answer to the question about the impact of services offered by point elements of transport infrastructure on meeting the expectations and preferences of passengers in various modes of transport. The aim of the research undertaken in the article is to assess the competitiveness of air transport and ferry shipping in servicing international passenger traffic in the BSR through the prism of time competitiveness of port ground access. The results of the research undertaken in the article do not exhaust the issue of competitiveness of the analyzed transport branches from the point of view of the quality of services provided by seaports and airports. Nevertheless, they can be an introduction to further in-depth research in this area, in particular those undertaking a comparative analysis of other elements affecting the quality of port services in passenger traffic.

\section{Literature overview}

The concept of competitiveness is analyzed on many levels. It is the ability to achieve market objectives in a competitive environment [9]. M. E. Porter [10] defines competitiveness as the ability to create conditions conducive to the development of international competitiveness of enterprises within specific market segments. In the area of passenger transport, competition is examined primarily from the point of view of satisfying the customer's preferences (travel mode choice behavior). The issue of travel mode choice behavior was taken, among others in studies by McFadden, Jackson \& Jucker, Ye \& Wang, Hunecke, Scheiner, Paulssen, De Vos et. all [11-18]. In the inter-branch transport system, the subject of many studies is the competitiveness between high-speed train and air transport [1923]. These studies confirm that cost and time are the two main factors that passengers take into account when travelling.

These factors also play a decisive role in the decisions of ferry passengers and air transport. Research in this area is relatively rarely undertaken [24-27]. They show that the main factor in the competitiveness of air transport in relation to ferry shipping is lower cost and the possibility of taking a car. In contrast, less time consuming in comparison with the ferry travel is a major factor in the competitiveness of air transport. There is also no comprehensive research in the literature on the assessment of the competitiveness of ferry and air transport through the prism of the quality of services provided by seaports and airports. Such research is undertaken rather in the inner-branch transport system. For example, Pantouvakis [28], in relation to seaports identified six factors (service, safety and security and cleanliness, communication, guidance and information) that effectively describe the multidimensional construct of port-service quality. Important factors of competitiveness of airports and sea terminals are resource factors that M.E. Porter describes as factor endowment [10]. They are connected, among others, with physical resources such as geographic location and time availability. 
In the transport literature, when analyzing the accessibility issues among others the connectivity factor is used [29-31]. Doganis and Denis [32-34] define this as the number of indirect connections that meet the minimum and maximum time requirements for passenger service in the port, taking routing into account. Veldhuis, Burghouwt, Kroes, Danesi, Malighetti and Paleari with their teams [29-30, 35-38] interpret connectivity similarly. In their opinion connectivity is defined as the number of direct and indirect connections, so that the passenger has a guaranteed stay in the transfer port, with the appropriate quality of services provided. The time availability of seaports and airports from the point of view of the port ground access is of significant importance in the broadly understood air- and seaport connectivity [39-44]. The main factors affecting the time availability (connectivity) are: accessilibity coefficient, time coordination of airport operators' service, air travel time, quality of service in the transit port, type of connection, maximum number of travel stages, type of connectivity (through the hub port or through other ports) [45-46]. Tłoczyński [47], analyzing the problems of the airport ground access system, distinguishes three paths of the analyzed problem:

- in terms of time needed for access to the airport,

- in terms of travel costs, car parking (these are the features that can be dimensioned in terms of money),

- competition between the systems that make up the airport / ferry links system (the passenger then uses all possible instruments to value the way of reaching the sea- or airport).

However, Koster, Kroes and Verhoef [48] proposed a model that defines the ideal time needed to reach the port, so that the passenger is neither too early nor too late, at an acceptable cost. As a result of the development of the passenger access system to seaports and airports, the importance of the region increases, then operators are more willing to launch new connections, increase the frequency of existing connections, and this in turn affects further development of the region [49].

Taking into account the above, the main issue raised in the article is the issue of the competitiveness of seaports and airports in handling passenger traffic through the prism of time competitiveness of airport and seaport ground access.

\section{Methodology}

The subject of research are selected airports and ferry terminals located in the main BSR cities. As an area of the BSR, an area covering territories belonging to countries with direct access to the Baltic Sea, including through the Danish straits, was adopted. In the analyzed area, the most important airports and seaports were selected. The main factors of selection were:

1. The volume of serviced international passenger traffic.

2. Representativeness of most countries in the region (apart from Poland and Germany, capitals of the Baltic countries were adopted).

3. Existence of alternative air and ferry connections.

The analysis excluded ferry terminals serving domestic traffic (e.g. within the Norwegian coast) and very short relations for which there are no alternative air connections, e.g. from the Swedish city of Helsingborg to the Danish city of Helsingør as well as the Danish town of Rødby to the German town of Puttgarden [27]. According to the criterion of representativeness of BSR countries, from the group of airports and ferry terminals, those serving the capitals of particular BSR countries were selected. The exceptions are Poland and Germany, for which airports and ferry terminals located in the coastal regions - Gdańsk, Gdynia and Rostock - were accepted. The indicated origin ferry ports and airports are served by air and ferry connections. The final group of transport hubs (origin ports) that were examined are: Copenhagen, Gdansk and Gdynia, Helsinki, Klaipeda, Oslo, Riga, Rostock, 
Stockholm and Tallinn. The Multiple Case Study Design method was used in the analysis of selected airports and ferry terminals [50]. Airports and ferry terminals were subjected to a comparative analysis according to the following criteria:

- location in relation to the city center $(\mathrm{km})$,

- directional structure of served connections (origin ferry ports and airports),

- frequency of connections (per week),

- time availability to the city center (minutes) separately for individual car and public transport (urban and rail).

Most of the analyzed points in which passengers start their journey ( 6 out of 9 ) were served by more than one ferry terminal, and two of them by more than one airport. In order to compare the estimated time of transfer on the route from the ferry terminal to the city center and from the airport to the city center in the case of the accessibility of more than 1 transport point for a specific transport branch (ferry terminal or airport), only the shortest (minimum) and longest (maximum) travel time were taken into account. In the analysis of the time availability of selected terminals and airports, the data generated by google.maps were used primarily. This data was taken for car traffic and public transport (including rail) in the same time and period (January 2018). In the absence of data on Google Maps for public transport in Gdansk, Klajpeda and Riga, data from the internet portals dedicated to public transport timetables were used [51-53].

\section{Results}

\subsection{The comparative analysis of ferry terminals and airports (location, traffic volume and connections)}

When making a comparative analysis of the analyzed airports and ferry terminals in the scope of passenger service, the sum of all transport points serving the city was taken into account. The analysis of the data shows that in the majority of the cities studied, a higher volume of passenger traffic is served by airports than ferry terminals. The exception is Tallinn and Rostock, where larger volumes of traffic are generated by ferry terminals. The most balanced branch structure of passenger traffic is served in Helsinki and Klaipeda. (Figure 1). 


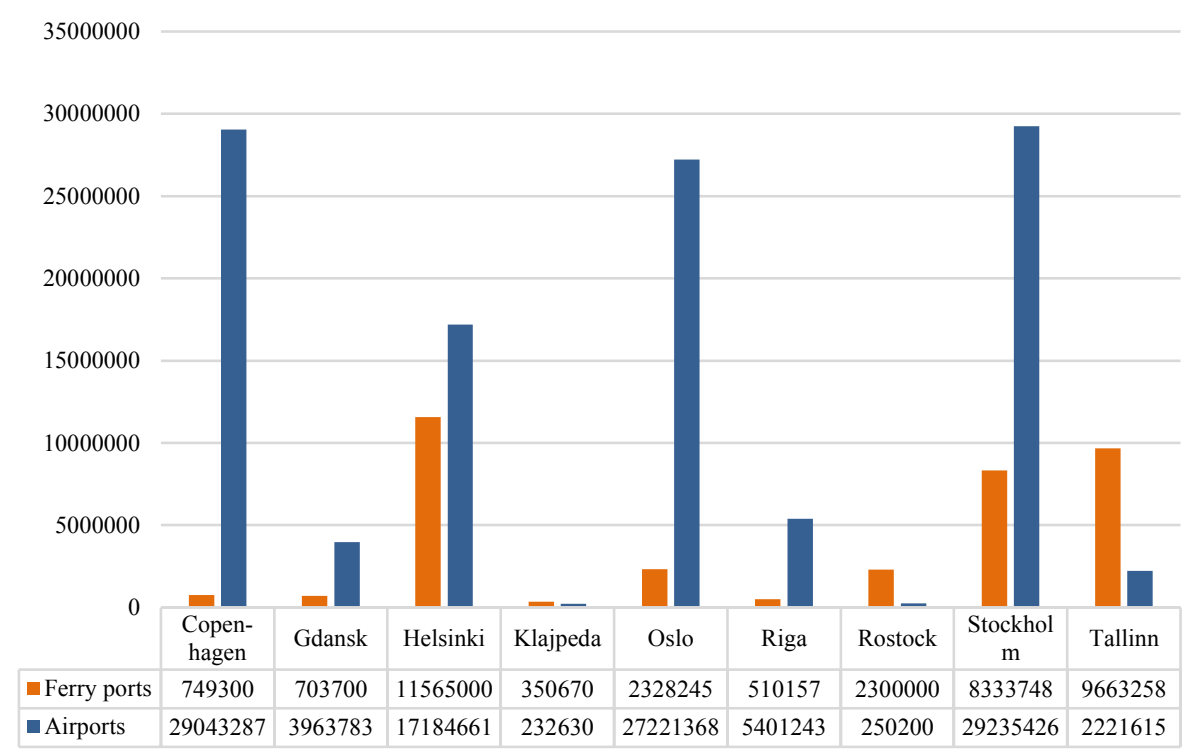

Fig. 1. The volume of passenger traffic served by the examined airports and ferry terminals in 2016 [54-63].

In the surveyed group of origin ports, the largest number of separate ferry terminals operates in Helsinki, 6 ferry terminals are located there. The analysis excluded Hansa Terminal, which handles the Helsinki-Travemünde route with the prevailing cargo traffic. Three ferry terminals also serve Stockholm and Tallinn. In the case of Tallin, ferry services for ferry operators of Viking Line, Eckerö Line and Moby Line SPL's were separated into two separate terminals according to departures and arrivals (successively terminal A and terminal B). The third terminal D serves only Tallink Silja ferries. Two ferry terminals also serve Oslo, Klaipeda and Gdansk. In the case of Gdańsk, Gdynia Ferry Port was accepted as the second terminal. Other analyzed cities such as: Copenhagen, Riga and Rostock are served by one ferry terminal. Specification of the analyzed ferry terminals and the distance from the city center is presented in Table 1.

Table 1. The distance of the analyzed ferry terminals from the city center [64]

\begin{tabular}{|l|r|}
\hline destination & distance from the city center (km)* \\
\hline Copenhagen & 4,5 \\
\hline Gdańsk & \\
Westerplatte Ferry Terminal & 10 \\
\hline Gdynia Ferry Port & 36,5 \\
\hline Helsinki & \\
Katajanokka Terminal & 3 \\
\hline West terminal 1 & 3 \\
\hline West terminal 2 & 4 \\
\hline Makasiini Terminal & 2,5 \\
\hline Olympia terminal & 3 \\
\hline Klajpeda & \\
International Ferry Terminal (IFT) & 13 \\
\hline Central Klaipedos Terminal (CKT) & 3,5 \\
\hline Oslo & 2 \\
DFDS Seaways and Stena Line Terminal & 3,5 \\
\hline Color Line Terminal & 1,5 \\
\hline Riga & 2,5 \\
\hline Rostock & \\
\hline
\end{tabular}




\begin{tabular}{|l|r|}
\hline Stockholm & 14,5 \\
Viking Line terminal (Stadsgården) & 10 \\
\hline Värtahamnen port & 6 \\
\hline Ferry terminal Frihamnen & 1,5 \\
\hline Tallin & 2,5 \\
\hline Passenger terminal A i B & \\
\hline Passeneger terminal D & \\
\hline
\end{tabular}

* the estimated distance was measured for car traffic and given to an accuracy of 500 meters.

13 out of 19 analyzed ferry terminals were located not more than $5 \mathrm{~km}$ from the city center, and as many as 9 of them are located not more than $3 \mathrm{~km}$ from the city center. The nearest ferry terminals are located in Oslo, Riga and Tallinn. At a distance of more than 5 $\mathrm{km}$, but no more than $10 \mathrm{~km}$ from the city center, there are 3 of the 19 analyzed terminals. Only 3 of the analyzed terminals are located more than $10 \mathrm{~km}$ from the city center. These include Gdynia Ferry Port, Stockholm (Viking Line terminal) and Klaipeda (International Ferry Terminal). In the case of the ferry terminal in Gdynia, the distance from the city center is explained by the fact that the city of Gdańsk was accepted as the destination, not Gdynia (the distance between the center of Gdynia and the terminal is $5 \mathrm{~km}$ ).

For the purposes of comparative analysis, the most important airports serving passenger air traffic, the location of which coincides with ferry terminals, were chosen. With regard to transport, most airports are located in the area of Stochkolm (Arlanda, Skavsta and Bromma) and in Oslo (Gardermoen, Sandefjord-Torp and Moss-Rygge), three air transport points. However, during the analyzed time period (January 2018), the airport serving the Oslo MossRygge region was closed. However, for the remaining agglomerations, one airport was assumed for the needs of research, despite the fact that in close proximity to Danish Copenhagen Airport operates the Swedish port of Malmö-Sturup, serving low-cost traffic (distance $51 \mathrm{~km}$ ). There are no premises related to cooperation between these ports, and one city from each country was selected for the research. Including Malmo as an origin port would cause inconsistency with the research assumptions. The distances between the particular ports and the city center are presented in Table 2.

Table 2. The distance of the analyzed airports from the city center [64]

\begin{tabular}{|l|r|}
\hline \multicolumn{1}{|c|}{ destination } & distance from the city center (km)* \\
\hline Copenhagen & 7 \\
\hline Helsinki & 20 \\
\hline $\begin{array}{l}\text { Oslo } \\
\text { Oslo Gardermoen }\end{array}$ & 49,5 \\
\hline Oslo Torp & 119 \\
\hline $\begin{array}{l}\text { Stockholm } \\
\text { Stockholm Arlamda }\end{array}$ & 41,5 \\
\hline Stockholm Skavsta & 106 \\
\hline Stockholm Bromma & 8 \\
\hline Riga & 10,5 \\
\hline Talinn & 7 \\
\hline Klajpeda & 8 \\
\hline Gdańsk & 16,5 \\
\hline Rostock & 45 \\
\hline
\end{tabular}

* the estimated distance was measured for car traffic and given to an accuracy of 500 meters.

The examined airports are located at a much greater distance from city centers than ferry terminals. Of the 12 examined airports, the four nearest airports were within $10 \mathrm{~km}$ of the city center (airports in Tallinn, Copenhagen, Klajpeda and Stockholm Bromma). The remaining 8 airports are located at a distance of more than $10 \mathrm{~km}$. The airports of Oslo Torp and Stockholm Skavsta are located farthest from the city centers (over $100 \mathrm{~km}$ ). 
Unlike airports, the analyzed ferry terminals support only BSR traffic, which is a natural feature of ferry shipping and results from its regional character [27]. The most popular ferry route is the Helsinki-Tallinn line with the frequency of weekly flights at 94 . According to the duration, this route is one of the longest in the BSR (long duration voyages of over 11 hours, [65] and the journey lasts, depending on the ferry operator, 16-17 hours. The second Baltic route with the highest frequency of sailings is the Rostock-Gedser route, which is classified as a short-term route (short duration voyages of up to 2 hours). The travel on this route lasts $1 \mathrm{~h} 45 \mathrm{~min}$. Connections with relatively high frequency of sailings per week (over 10) also include ferry services on the Rostock-Trelleborg, Stockholm-Turku, Gdynia Karlskrona and Helsinki-Stockholm routes. However, the lowest frequency sailings include connections with the Baltic with the Russian Federation, i.e. services from Helsinki, Stockholm and Tallinn to St. Petersbug. This is due to their typically tourist nature (ferry cruise, round trip) with a cruise time of over 62 hours from Tallin to St. Petersburg.

Table 3. Structure and frequency of connections in the analyzed ferry terminals [66]

\begin{tabular}{|c|c|c|}
\hline ferry ports & destinantion & frequency (weekly) \\
\hline Copenhagen & Oslo & 7 \\
\hline \multirow{2}{*}{ Gdańsk i Gdynia } & Nynäshamn (Stockholm) & 3 \\
\hline & Karlskrona & 18 \\
\hline \multirow{4}{*}{ Helsinki } & Sztokholm & 7 \\
\hline & Tallin & 94 \\
\hline & St. Pettersburg & 2 \\
\hline & Sztokholm & 15 \\
\hline \multirow[t]{2}{*}{ Klaipeda } & Karlshamn & 7 \\
\hline & Kiel & 7 \\
\hline \multirow[t]{3}{*}{ Oslo } & Copenhagen & 7 \\
\hline & Frederikshavn & 7 \\
\hline & Kiel & 7 \\
\hline Riga & Sztokholm & 7 \\
\hline \multirow[t]{2}{*}{ Rostock } & Trelleborg & 33 \\
\hline & Gedser & 68 \\
\hline \multirow[t]{5}{*}{ Stockholm } & Helsinki & 15 \\
\hline & Turku & 28 \\
\hline & Tallin & 8 \\
\hline & Ryga & 7 \\
\hline & St. Petersburg & 1 \\
\hline \multirow[t]{3}{*}{ Tallin } & Helsinki & 94 \\
\hline & Sztokholm & 8 \\
\hline & St. Petersburg & 1 \\
\hline
\end{tabular}

The analyzed airports play a different role in the transport system. Copenhagen, Stockholm Arlanda, Oslo Gardermoen and Helsinki are typical hub ports, others play a role in regional service (Gdańsk, Torp, Skavsta, Riga and Talinn) and local service (Bromma, Klaipeda and Rostock) (see Table 4). This means that the nature of ports enforces differentiation of the network of connections. While the network of connections from ports located in the BSR to hub ports may be one of the elements of the journey (airline travels through the "hub and spoke" system, connections between regional and local ports have a typical direct character - "point to point").

In the group of the analyzed airports, the largest share of connections within the BSR in the total number of connections (taking into account their frequency) have Stockholm Bromma airports (88.5\%), Klaipeda (84\%), Tallinn (70.9\%) and Stockholm Arlanda $(50.6 \%)$. The lowest proportion of connections within the framework of the BSR in general are carried out on Oslo Gardemoren and Stockholm Skavsta airports (less than 15\%). Rostock 
airport does not make any air connections to BSR ports, which is largely due to its local nature and proximity to international airports in Berlin (catchment area overlap).

Table 4. Connections of the examined airports under the BSR [55-63]

\begin{tabular}{|l|r|r|r|r|r|}
\hline \multicolumn{1}{|c|}{ airports } & destination & airports BSR & $\begin{array}{c}\text { total } \\
\text { connection } \\
\text { during week }\end{array}$ & $\begin{array}{c}\text { total } \\
\text { connection } \\
\text { during week } \\
\text { to BSR }\end{array}$ & BSR/total \\
\hline Copenhagen & 95 & 13 & 2373 & 791 & 33.3 \\
\hline Helsinki & 104 & 15 & 1739 & 636 & 36.6 \\
\hline Oslo Gardermoen & 111 & 11 & 2324 & 324 & 13.9 \\
\hline Oslo Torp & 29 & 3 & 128 & 33 & 25.8 \\
\hline Stockholm Arlamda & 132 & 24 & 2346 & 1188 & 50.6 \\
\hline Stockholm Skavsta & 35 & 2 & 115 & 17 & 14.8 \\
\hline Stockholm Bromma & 15 & 12 & 592 & 524 & 88.5 \\
\hline Riga & 68 & 9 & 663 & 209 & 31.5 \\
\hline Talinn & 25 & 5 & 199 & 141 & 70.9 \\
\hline Klajpeda Palanga & 5 & 3 & 25 & 21 & 84.0 \\
\hline Gdańsk & 59 & 10 & 332 & 95 & 28.6 \\
\hline Rostock & 8 & 0 & 27 & 0 & 0.0 \\
\hline
\end{tabular}

\subsection{The comparative analysis of ferry terminals and airports through the prism of time competitiveness of ground access}

The comparative analysis of transfer time from the analyzed ferry terminals and airports to the centers of the cities served by them was carried out in two variants:

- for transfers carried out individually by road transport, assuming the possibility of renting a passenger car at an airport or travelling by ferry with a passenger car,

- for transfers made using public transport (urban and rail).

In the case of the availability of various forms of public transport, the comparative analysis takes into account those with the shortest duration, i.e. rail links to airports in Copenhagen, Oslo Gardemoren, Stockholm Arlanda and Gdańsk. The results of the comparative analysis are presented in Figures 2 and 3. 


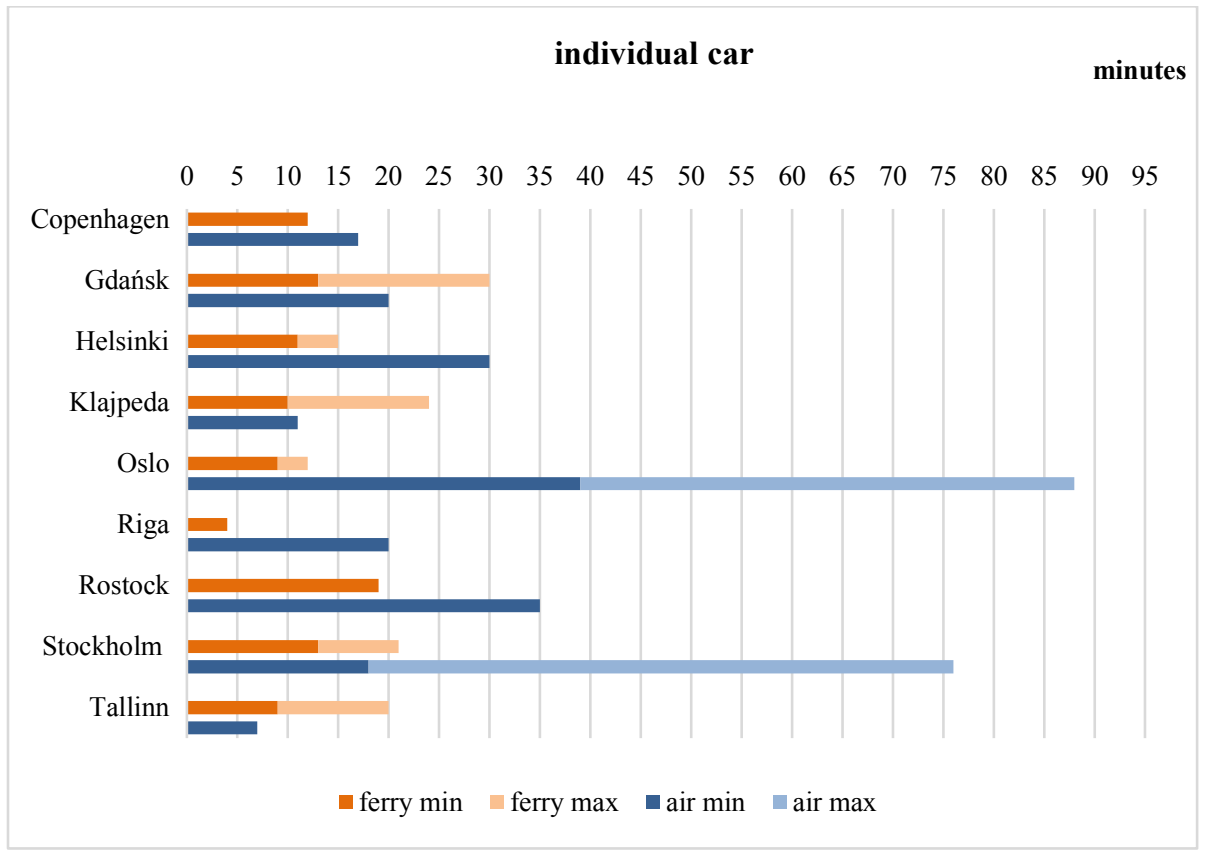

Fig. 2. Comparison of travel time by car from the city center to the ferry terminal and airport [51-53, 64].

\section{public transport}

\section{minutes}

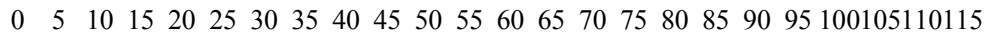

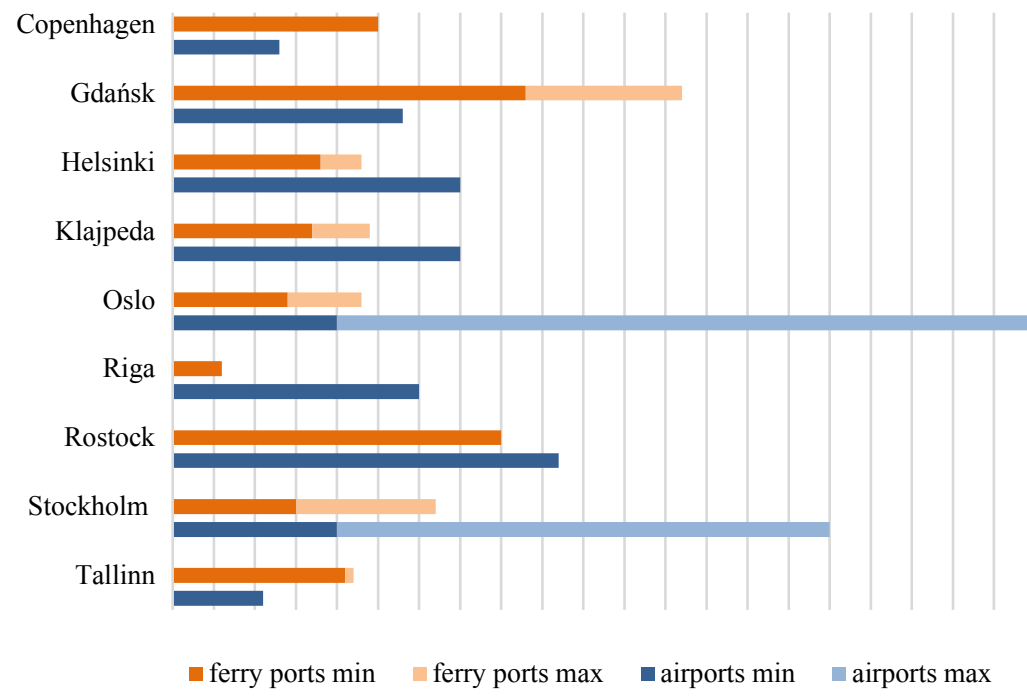

Fig. 3. The comparison of public transport travel time from the city center to the ferry terminal and airport [51-53, 59-60, 63-64, 67-71]. 
In most of the analyzed origin ferry ports and airports, a shorter estimated time of arrival by car from the transport point to the city center was noted in the case of ferry terminals. The longer maximum time of arrival from the ferry terminal to the center in relation to the transfer from the airport occurs in Tallinn, Klaipeda and Gdańsk. Besides, apart from Tallinn, it concerns transfers only from points further located of ferry terminals. The largest difference in the estimated transfer times concerns Stockholm and Oslo. This is due to the remote location of airports to the city centres.

The comparative analysis carried out for public transport showed that for some origin ports, the time competitiveness of ferry terminals relative to airports in terms of transfer time to the city center (Copenhagen) - decreased, or conversely- the time competitiveness of transfers from ferry terminals at the expense of longer transfers from airports (Klaipeda) increased. In the case of ferry terminals in Rostock and Stockholm, as in the case of car travel, the time of transfer to the city center by public transport is shorter than access from alternative airports. Nevertheless, it was relatively prolonged while reducing the transfer time from alternative airports. In the case of Gdańsk, the difference between the shorter time of arrival from the airport to the city center and the time of transfer from the ferry terminal, as compared to car travel, deepened. The situation hardly changed in the case of Helsinki, Oslo and Riga. It should be emphasized that dedicated railway connections to airports, which are available in some of the analyzed origin airports, significantly shorten the transfer time to the city center. In the case of Oslo Gardemoren and Copenhagen, this is over $62 \%$ in relation to bus connections, and Stockholm Arlanda more than 57\%. Only in the case of Stockholm Skavsta travel by train takes longer than public transport.

\section{Conclusions}

The results of the comparative analyzes of the time competitiveness of airport and seaport ground access in the BSR allow to make a general conclusion that ferry terminals have better ground access for individual car journeys. This corresponds to the preferences of ferry passengers which were identified in the other research, who consider it the best option to travel with a car [24, 27]. Ferry terminals in terms of time competitiveness of ground access strengthen their position of ferry shipping in servicing the segment of motorized passengers. The longer time of reaching the destination by public transport results, in the majority of the analyzed cases, due to the lack of dedicated connections by public transport from ferry terminals to the city center (especially railway).

However, airports are becoming more competitive in terms of ground access in the case of the arrival and departure function of public transport. The research additionally indicated that the transfer time of public transport from the analyzed airports to the city center is definitely reduced due to the functioning of airport rail links. As a result, airports are able to meet the main demands made by passengers (time, immediacy, frequency, lack of congestion) thanks to more time-based railway transfers [72]. It should be pointed out that the lower availability of individual transport to airports is mainly due to the large distance between airports and the city center and high fees for the use of parking infrastructure. The airports to a greater extent meet the expectations of individual passengers who make transfers using public transport than ferry terminals.

Summing up, it should be stated that the system of ground access for seaports and airports is adapted to the segment of passengers having the largest share in transport by the analyzed transport branches, i.e. the motorized passengers in ferry transport and non-motorized passengers in air transport. 


\section{References}

1 P. Freathy, \& F. O'Connell, Strategic reactions to the abolition of duty free:: Examples from the European airport sector. Euro. Man. J., 18, 638-645 (2000)

2 A. Gebauer, C.W. Nam, \& R. Parsche, Lessons of the 1999 abolition of intra-EU duty free sales for the new EU member states. CESifo Econ. St., 51, 133-157 (2005)

3 T. Wergeland, Ferry passenger markets. The Blackwell Comp. to Marit. Econ., 161$183(2012)$

4 A. Graham, Liberalization, regional economic development and the geography of demand for air transport in the European Union. J. Tran. Geog., 6, 87-104 (1998)

5 P. Morrell, Air transport liberalization in Europe: the progress so far. J. A. Tran. World Wide, 3, 42-60 (1998)

6 A. Micco \& T. Serebrisky, Competition regimes and air transport costs: The effects of open skies agreements. J. Int. Econ., 70, 25-51 (2006)

7 X. Fu, T. H. Oum, \& A. Zhang, Air transport liberalization and its impacts on airline competition and air passenger traffic. Tran. J., 24-41 (2010)

8 K. Button, The impact of US-EU "Open Skies" agreement on airline market structures and airline networks. J. A. Tran. Man., 15, 2, 59-71 (2009)

9 K. Moszkowicz, M. Moszkowicz, Konkurencyjność i innowacje - gdzie szukać szansy?. Tożs. Str. Przed. - modele i doświadczenia. M. Moszkiewicz (ed.), 110, (House Publ. Technical Wrocław University, 1997)

10 M.E. Porter, The Competitive Advantage of Nations, 70-72 (Macmillan Press Ltd, 1986).

11 D. McFadden, Conditional logit analysis of qualitative choice behavior (1973)

12 W.B. Jackson \& J.V. Jucker, An empirical study of travel time variability and travel choice behavior. Tran. Sc., 16, 460-475 (1982)

13 Y.L. Ye \& Y.S. Wang, Research on travel mode choice behavior in ShanghaiHangzhou transport corridor. J. China Rail. Soc., 32, 13-17 (2010)

14 M. Hunecke, A. Blöbaum, E. Matthies \& R. Höger, Responsibility and environment: Ecological norm orientation and external factors in the domain of travel mode choice behavior. Env. Beh., 33, 830-852 (2001)

15 J. Scheiner \& C. Holz-Rau, Travel mode choice: affected by objective or subjective determinants?. Transportation, 34, 487-511 (2007)

16 A. Vij, A. Carrel \& J.L. Walker, Incorporating the influence of latent modal preferences on travel mode choice behavior. Tran. Res. Part A: Pol. Prac., 54, 164178 (2013)

17 M. Paulssen, D. Temme, A. Vij \& J.L. Walker, Values, attitudes and travel behavior: a hierarchical latent variable mixed logit model of travel mode choice. Tran., 41, 873-888 (2014)

18 J. De Vos, P.L. Mokhtarian, T. Schwanen, V. Van Acker \& F. Witlox, Travel mode choice and travel satisfaction: bridging the gap between decision utility and experienced utility. Tran., 43, 771-796 (2016)

19 J.C. Martín, C. Román, J.C. García-Palomares \& J. Gutiérrez, Spatial analysis of the competitiveness of the high-speed train and air transport: The role of access to terminals in the Madrid-Barcelona corridor. Tran. Res. Part A: Pol. Prac., 69, 392408 (2014)

20 D. Albalate, G. Bel \& X. Fageda, Competition and cooperation between high-speed rail and air transportation services in Europe. J. Tran. Geog., 42, 166-174 (2015)

21 T. D’Alfonso, C. Jiang \& V. Bracaglia, Would competition between air transport and high-speed rail benefit environment and social welfare?. Tran. Res. Part B: Meth., 74, 118-137 (2015) 
22 W. Xia \& A. Zhang, High-speed rail and air transport competition and cooperation: A vertical differentiation approach. Tran. Res. Part B: Meth., 94, 456-481 (2016)

23 W. Rothengatter, High-speed rail and air travel complementarity: the case of Germany. High-Speed Rail and Sustainability, (Routledge, 123-134, 2017)

24 E. Sambracos, Air-sea transport: competitiveness or complementarity in the Greek insular market. (Inter. Con. A. Tran. A. evol. in the 21st Century, 3-4, 2001)

25 K. Rigas, Boat or airplane? Passengers' perceptions of transport services to islands. The example of the Greek domestic leisure market. J. Tran. Geo., 17, 396-401 (2009)

26 K. Rigas, E. Sambracos, \& A. Gatzoli, Air and sea transport: Competition strategies under normal and economic crisis environments. SPOUDAI-J. Econ. Bus., 61, 6584 (2013)

27 M. Mańkowska, The concept of development of passenger ferry services in the Baltic sea region in terms of the growing interbranch competition. (17th Inter. Conf. Tran. Sc. Slovenia: Mar. Tran. Log. Sc., 2015)

28 A. Pantouvakis, Port-service quality dimensions and passenger profiles: an exploratory examination and analysis. Mar. Econ. \& Log., 8, $402-418$ (2006)

29 P. Malighetti, S. Paleari \& R. Redondi, Connectivity of the European airport network:"self-help hubbing" and business implications. J. A. Tran. Man., 14, 53-65 (2008)

30 S. Paleari, R. Redondi, P. Malighetti, A comparative study of airport connectivity in China, Europe and US: which network provides the best service for passengers?. Tran. Res., 42, 198-210 (2010)

31 G. Burghouwt, R. Redondi, Connectivity in Air Transport Networks. An Assessment of Models and Applications. J. Tran. Econ. Pol., 47, 1, 37-41 (2013)

32 N. Dennis, Airline hub operations in Europe. J. Tran. Geog., 2, 219-233 (1994)

33 N. Dennis, Scheduling strategies for airline hub operations. J. Tran. Man., 1, 131144 (1994)

34 N. Dennis, R. Doganis, Lessons in Hubbing, A. Bus., 3, $42-47$ (1989)

35 J. Veldhuis, The competitive position of airline networks. J. A. Tran. Man., 3, 181188 (1997)

36 G. Burghouwt, J. Veldhuis, The competitive position of hub airports in Transatlantic market. J. A. Tran., 11, 1, 106-130 (2006)

37 J. Veeldhuis, E. Kroes Dynamics in relative network perfornance of the main European hub airports, (Proceeding of the Eur. Tran. Conf. Cambridge, 9-11 September 2002)

38 A. Danesi, Measuring airline hub timetable co-ordination and connectivity: definitione of a new index and application to a sample of European hubs. Euro. Tran., 34, 54-74 (2006)

39 M.L. Tam, W.H. Lam \& H.P. Lo, Modeling air passenger travel behavior on airport ground access mode choices. Transportm., 4, 135-153 (2008)

40 D.A. Tsamboulas, \& A. Nikoleris, Passengers' willingness to pay for airport ground access time savings. Tran. Res. Part A: Pol. Prac., 42, 1274-1282 (2008)

41 M.L. Tam, W.H. Lam \& H.P. Lo, Incorporating passenger perceived service quality in airport ground access mode choice model. Transportm., 6, 3-17 (2010)

42 R.C. Jou, D.A. Hensher \& T.L. Hsu, Airport ground access mode choice behavior after the introduction of a new mode: A case study of Taoyuan International Airport in Taiwan. Tran. Res. Part E: Log. Tran. Rev., 47, 371-381 (2011)

43 T. Budd, T. Ryley, \& S. Ison, Airport ground access and private car use: a segmentation analysis. J. Tran. Geog., 36, 106-115 (2014) 
44 I. Gokasar \& G. Gunay, Mode choice behavior modeling of ground access to airports: A case study in Istanbul, Turkey. J. A. Tran. Man., 59, 1-7 (2017)

45 G. Burghouwt, \& R. Redondi, Connectivity in air transport networks: an assessment of models and applications. J. Tran. Econ. Pol., 47, 1, 35-53 (2013)

46 D. Tłoczyński, Konkurencja na polskim rynku usług transportu lotniczego, (University of Gdańsk Publisher, 2016).

47 D. Tłoczyński, The analysis of transport accessibility in airports as the part of the competitiveness in regions. Case study of Polish Airports, (17th Inter. Conf. Tran. Sc. Slovenia: Mar. Tran. Log. Sc., 2015)

48 P. Koster, E. Kroes, E.T. Verhoef, Travel Time Variability and Airport Accessibility, Tinb. Inst. Disc. Pap., 061/3, 7 (2010)

49 A. Reynolds-Feighan, P. McLay, Accessibility and attractiveness of European airports: A simple small community perspective. J. A. Tran. Man., 12, 315 (2006)

50 R.K. Yin, Case Study Methods., Handbook of complementary methods in education research J. L. Green, G. Camilli, \& P. B. Elmore (Eds.). 111-122 (2006)

51 Stops.lt downloaded from www.stops.lt (10.01.2018)

52 Rīgas satiksme. downloaded from saraksti.rigassatiksme.lv (10.01.2018)

53 Moovit. downloaded from moovitapp.com (10.01.2018)

54 ShipPax Information, (Sweden, 2017)

55 Avinor. downloaded from https://avinor.no (10.01.2018)

56 Copenhagen Airport. downloaded from www.cph.dk (10.03.2018),

57 Gdansk Airport. downloaded from www.airport.gdansk.pl (10.02.2018)

58 Finavia airports. downloaded from www.finavia.fi (10.01.2018)

59 Palanga Airport. downloaded from www.palanga-airport.lt (10.01.2018)

60 Riga Airport. downloaded from www.riga-airport.com (10.01.2018)

61 Rostock Airport. downloaded from www.rostock-airport.de (10.01.2018)

62 Swedavia airports. downloaded from www.swedavia.se (10.01.2018)

63 Tallin Airport. downloaded from www.tallinn-airport.ee (10.01.2018)

64 Google.maps. downloaded from: www.google.com/maps (10.01.2018)

65 I. Kotowska, Short Sea Shipping in the light of the idea of sustainable development of transport (Szczecin: Sc. Publ. Hou. Mar. Univ. 2014)

66 Direct Ferries. downloaded from www.directferries.com (10.01.2018)

67 Tripadvisor. downloaded from https://www.tripadvisor.com (10.01.2018)

68 Visitcopenhagen. downloaded from https://www.visitcopenhagen.com (10.01.2018)

69 Visitoslo. downloaded from http://www.visitoslo.com (10.01.2018)

70 Visitstockholm. downloaded from https://www.visitstockholm.com (10.01.2018)

71 ZTM. downloaded from www.ztm.gda.pl (10.01.2018)

72 D. Tłoczyński, M. Wołek, Komplementarność i substytucja $w$ pasażerskim transporcie kolejowym i lotniczym. Procesy integracyjne wybranych systemów transportowych, M. Michałowska (ed.), (Academic of Economy in Katowice, 263, 2007) 